\title{
Credit Management in Cooperative Banks - An Exploratory Study of DCC Bank Shivamogga District
}

\author{
Dr. Mahesha. V. \\ Assistant Professor \\ Department of Post Graduate Studies and Research in Commerce, \\ Karnataka State Open University, \\ Muktagangotri, Mysuru - 06.
}

\begin{abstract}
In the new millennium, the co-operatives are to play a pivotal role and act as agencies of economic growth, creating wealth and employment opportunities especially in the rural areas. The United Nations declared 2012 as International Year of Co-operatives. The theme of this year is "Co-operative enterprises help to build a better world". The logo of the International Year of Co-operatives is a cube lifted and supported by seven people. It represents autonomous association of persons united voluntarily to meet their common economic, social, and cultural needs and aspirations through a jointly owned and democratically controlled enterprise. So in this background the current study assume greater importance to study credit management in cooperative banks.
\end{abstract}

Key words: Credit Management, Cooperative Bank, DCC Bank, Agriculture, Commercial banks

\section{Introduction}

A co-operative bank is a financial entity which belongs to its members, who are at the same time the owners and the customers of their bank. Co-operative banks are often created by persons belonging to the same local or professional community or sharing a common interest. Cooperative banks generally provide their members with a wide range of banking and financial services and assistance (loans, deposits, banking accounts etc.). Co-operative banks differ from stockholder banks by their organization, their goals, their values and their governance. In most of the countries, they are supervised and controlled by banking authorities and have to respect prudential banking regulations, which put them at a level playing field with stockholder banks. Depending on countries, this control and supervision can be implemented directly by state entities or delegated to a co-operative federation or central body. Co-operative banking is retail and commercial banking organized on a cooperative basis. Co-operative banking institutions take deposits and lend money in most parts of the world. Cooperative banking, includes retail banking, as carried out by credit unions, mutual savings and loan associations, building societies and co-operatives, as well as commercial banking services provided by manual organizations (such as co-operative federations) to co-operative businesses.

Rural Cooperative Banking and Credit Institutions play an important role in meeting the growing credit needs of rural India. The volume of credit flowing through these institutions has increased voluminously. The performance of these institutions, however (apparent in the share of total institutional credit and the indicators of their financial health), has been less than satisfactory and is deteriorating rapidly. Of late, a number of Committees have gone into the reasons for this situation and suggested remedial measures, but there has been little progress in implementing their recommendations for the betterment and improving the current situation. 


\section{Credit Management}

The word "credit" comes from the Latin word "credo" which means "I believe". Hence, credit is based upon belief, confidence, trust and faith. The loan is based upon the confidence of borrower's future solvency and repayment. Hence, credit means ability to command the other's capital in return for a promise to re-pay at some specified time in future. Besides, credit is the combination of "ability to borrow" and "willingness to borrow". In fact, credit is an individual's borrowing capacity, often being considered as an "economic good" to be produced, managed and marketed.

Credit management is a term used to identify accounting functions usually conducted under the umbrella of accounts receivables. Essentially, this collection of processes involves qualifying the extension of credit to a customer, monitors the reception and logging of payments on outstanding invoices, the initiation of collection procedures, and the resolution of disputes or queries regarding charges on a customer invoice. When functioning efficiently, credit management serves as an excellent way for the business to remain financially stable.

In other words the Credit management is the process of controlling and collecting payments from customers. This is the function within a bank or company to control credit policies that will improve revenues and reduce financial risks.

The process of credit management begins with accurately assessing the credit - worthiness of the customer base. This is particularly important if the company chooses to extend some type of credit line or revolving credit to certain customers. Proper credit management calls for setting specific criteria that a customer must meet before receiving this type of credit arrangement. As part of the evaluation process, credit management also calls for determining the total credit line that will be extended to a given customer.

In spite of this position in 1920-21 and the subsequent onslaughts of the worldwide depression, the Royal Commission on Agriculture
(1928) was encouraged to point out that "experience has amply proved the advantage of this type as a foundation for more ambitious schemes. It affords an excellent training in the handling of money, in expending it on productive purposes, and in the elements that combine to build up sound credit." It frankly admitted that "in the present state of India, the money-lender is a necessity" but emphasized that "the importance of the co-operative movement is accentuated by the comparative failure of legislative measures designed to deal with the problem of indebtedness to achieve their objects." From this emerged its classical warning that "if co-operation fails, there will fail the best hope of rural India." The central banking enquiry committee and the provincial banking enquiry committees which undertook a more elaborate inquiry into the particular problem three years later endorsed the view of the agricultural commission and reiterated its faith in the potentialities by emphasizing that " the greatest hope of the salvation of rural classes from their crushing burden of debt rests in the growth and spread of a healthy and well organized cooperative movement based on the careful education and systematic training of the villagers themselves."

\section{District Central Co-operative Banks (DCCBs): A Special Mention}

When the first Co-operative Credit Societies Act was passed in 1904, there was no provision for the formation of DCCBs. But the Act 1912 permitted the organization of higher level federal societies. Before passing this Act of 1912, some Central Co-operative Banks had been established to cater to the financial needs and requirements of the primary societies. They were registered as PACS but were working as Central Co-operative Banks. However with the passing of the Cooperative Societies Act in 1912, District Central Co-operative Banks came to be established on a large scale in the country. The period from 1906 to 1918 may be called as the period of origin of the District Central Co-operative Banks in the country. 
The National Bank for Agriculture and Rural Development(NABARD) Act, 1981, provided the following definition of a Central Co-operative Bank: "Central Co-operative Bank means the principal co-operative society in a district of a state, the primary object of which is the financing of other co-operative societies in that district, provided that in addition to such principal society in a district or where there is no such principal society in a district, the State Government may declare any one or more co-operative societies carrying on the business of financing other cooperative societies in that district to be Central Co-operative Bank".

\section{Review of Earlier Work}

Ramesha K.(2001) made a study entitled "Credit Risk Management in Agricultural Co-operative Banks "in 2001. Given the rates of NPAs and chronic over dues, credit risk management assumes greater significance in Co-operative Banks. The inherent risk in agricultural lending makes credit risk management all the more important and burning requirement in Agricultural Credit Co-operatives. Needless to say, credit discipline should form the centre piece of the strategies for the survival and growth of PACBs.

Adinew Abate et at all, (2002) examined in their research study the magnitude and growth of institutional credit flow to agricultural sector in Karnataka. They observed that recovery performance of agricultural advances especially in the post-reform period had significantly improved in commercial banks, RRBs and DCCBs lending. Only the recovery performance of PCARDBs continued to decline. They suggested that the government and lending institutions should take stringent measures on willful and deliberate defaulters and then only the problem could be solved.

Singh and Singh (2006) studied the funds management in the District Central Cooperative Banks (DCCBs) of Punjab with special reference to the analysis of financial margin. The study noted that a higher proportion of own funds and the recovery concerns have resulted in the increased margin of the Central Co-operative Banks and thus had a larger provision for nonperforming assets (NPAs).

Bhagavati Prasad (2006) has clearly pointed in his article "Co-operative banking in competitive business environment" has examined the performance of co-operative credit and banking structure. The researcher has analyzed the critical problems faced by PACSs such as lack of diversification in business portfolio, low volume of business, declining percentage of borrowing membership, high cost of management, imbalances in loan outstanding, unskilled staff, lack of professionalism, weak MIS, involvement in less profitable PDS business and low interest margin.

Agricultural Finance Sub-Committee (1945) The committee clearly observed that, "the spread of co-operation would provide the best and the more lasting solution for problems of rural economy in general and that of agricultural credit in particular."However, it was considered that it might not possible for the cooperative movement to supply the entire credit needs of agriculturists. Therefore, it was recommended that state aid should be given in much larger measure that was provided in the past so that the co-operatives might be enabled to supply better credit facilities.

Co-operative Planning Committee (1945) Under the Chairmanship of R.G.Saraiya in 1945, the committee recommended that primary societies be converted into multipurpose societies and that efforts should be made to bring 30 per cent of the rural population and 50 per cent of villages within the ambit of the reorganized societies within a period of 10 years, 25 percent of the total marketable surplus or agricultural produce should come under co-operatives. Committee also recommended that Reserve Bank of India should provide greater assistance to cooperatives.

All India Rural Credit Survey or Gorwala Committee (1954) -The Committee was appointed by the Reserve Bank of India in 1951, 
to supervise a survey regarding facilities available in rural areas for providing agricultural loans to the agriculturists and to make necessary recommendations. The Committee submitted its report in 1954. After analyzing the various causes for unsatisfactory working of the movement, the committee concluded that "Co-operation has failed but it must succeed". The committee recommended-A) an "Integrated Scheme of Rural Credit? involving three fundamental principles, namely- i) State participation at different levels, ii) Co-ordination of credit with other economic activities especially processing and marketing in the co-operative sector, and iii) Administration through trained and efficient personnel responsible to the needs of the rural population. B) Suitable amendments were suggested in RBI Act and the establishment of a National Cooperative Development and Ware Housing Board at all India level. C) The establishment of three special funds under the RBI was suggested.ie. i) The National Agricultural Credit (long-term operations) Fund, ii) The National Agricultural (stabilization) Fund, iii) National Agricultural Credit (Relief and Guarantee) Fund. D) A crop loan system was to be evolved. E) The economic viability of the cooperatives at the village level was very much essential. Each village society should be revitalized and reorganized for the purpose of efficient and effective administration and be made really effective. These recommendations were generally approved and were made the basis for the future plans for development.

Law Committee (1956)- Law Committee was set up by Government of India, under the Chairmanship of S.T.Raja. The committee submitted its report in 1957 and prepared a draft bill, which was forwarded to all State Governments for simplifying and liberalizing the provisions of co-operative laws and procedures, with suitable modifications and amendments to their local conditions. The law related to cooperatives, their responsibility of enactment and administration rested in the State Governments. After the committee report, many State Governments passed their new Acts.

\section{Objectives of the Study}

Based on the Literature reviewed the primary objective of the study is to make "Credit Management in Cooperative Banks". However to structure the study in a lucid logical order the fallowing Secondary Objectives are formulated.

1. To elucidate the Credit Management system in DCC Banks

2. To evaluate the Effectiveness of Credit management by DCCBs from Employers perspective as well as customers perspective

3. To explore and compare growth in credit portfolio of DCCBs.

\section{Hypothesis}

In line with the objectives framed for the study, the researcher has set the following hypotheses in order to analyze the data statistically.

H01: Chances of layoff of Interest or loan itself is not a significant factor influencing for preferring cooperative banks over other peer group banks.

H02: The Overall Credit Evaluation Effectiveness of the DCCBs is not significant from the perspective of respondents with different income pattern.

H03: The DCCBs Credit Management issues in Purpose based loans offered are not significant.

\section{Sources of data}

The present study is based on both primary and secondary data. Primary data has been collected from the sample respondents by adopting convenience random sampling method through pre-tested questionnaire. The secondary data has been collected through sources like, Published articles, reports, papers, books etc.

Table 1: Gender Wise Respondents

\begin{tabular}{|l|l|l|}
\hline Gender & Frequency & Percentage (\%) \\
\hline Male & 128 & 59.8 \\
\hline Female & 86 & 40.2 \\
\hline Total & 214 & 100.0 \\
\hline
\end{tabular}

Source: Primary Data 
Table 1 show the gender wise classification of respondents participated in the study. The percentage of male is more than female respondents who have rendered their opinion on credit management of cooperative banks. 59.8 percent of the respondents are male and 40.2 percent of the respondents are female. It is to be noted that, Male respondents were more open and had been more responsive in responding to the scheduled questions. However the researcher made sincere attempt in majority of the instances to obtain equal responses from both gender with the help of bank employees.

Table 2: Age Wise Distribution of Respondents

\begin{tabular}{|l|c|c|}
\hline Age & Frequency & Percentage \\
\hline 20 Years to 30 Years & 22 & 10.3 \\
\hline 30 Years to 40 Years & 101 & 47.2 \\
\hline 40 Years to 50 Years & 59 & 27.6 \\
\hline 50 Years and above & 32 & 15.0 \\
\hline Total & 214 & 100 \\
\hline
\end{tabular}

Source: Primary Data

Table 2 shows the age wise classification of the respondents participated in the study. 10.3 percent of the respondents are of the age group between 20 years and 30 years, 47.2 percent of the respondents are of the age group between 30 years and 40 years, 27.6 percent of the respondents are of the age group between 40 years and 50 years and 15 percent of the respondents are above 50 years. It is to be noted that, most of the respondents above 40 years with more number of years of association with the bank had favorable and positive opinion in most of the cases but the same was not true with that of age group 20 to 30 years. It is observed that, the respondents of age group had more of comparative and competition based opinion on credit management of DCCBs and more to say on Ease of operation and use of Technology.
Table 3 Numbers of Years of Association with the Bank

\begin{tabular}{|l|c|c|}
\hline Number of Years & Frequency & Percentage \\
\hline Less than 1 Year & 11 & 5.1 \\
\hline 1 to 5 Years & 168 & 78.5 \\
\hline More than 5 Years & 35 & 16.4 \\
\hline Total & 214 & 100.0 \\
\hline
\end{tabular}

Source: Primary Data

Table 3 shows the number of years of association of the respondents with the bank involved in the study. 5.1 percent of the respondents are associated with the bank for less than one year. 78.5 of the respondents are associated with the bank between 1 and 5 years. 16.4 percent of the respondents are associated with the bank more than 5 years. The data clearly signifies that majority of customers are being associated with the bank for considerable number of years. However it is also important to note that actively involved number of young customers is very low compared other groups.

Factors supporting opinion of the respondents on attributes of the bank they are associated with The Karl Pearson's Co-efficient of Correlation measures how variables or rank orders are related. This is useful in a linear relationship among variables. It also develops the linear parametric relationship among any of the factors. When two variables are continuous in nature and exploring relationship between or among variables correlation is apt statistical tool to find Numerical estimates of the correlation coefficient and test for the statistics significance of the correlation coefficient. Pearson correlation coefficient is denoted by " $r$ " which always by definition lies between -1 and +1 . Interpretation for $r$-value should normally be as follows.
$0.0-0.2$
poor correlation
$0.2-0.4$
fair correlation
$0.4-0.6$
Moderate correlation
$0.6-0.8$
good correlation
$0.8-1.0$ 
Table 4: Correlation coefficient for the opinion of the respondents on attributes of the bank they are associated with

\begin{tabular}{|l|l|l|l|}
\hline Attributes & \multicolumn{3}{l|}{ Factor supporting } \\
\hline & $\begin{array}{l}\text { Pearson } \\
\text { Correlation }\end{array}$ & $\begin{array}{l}\text { Sig. (1- } \\
\text { tailed) }\end{array}$ & N \\
\hline Subsidized Interest Loans & 0.708 & 0.001 & 214 \\
\hline Attractive Interest Rates & 0.635 & 0.000 & 214 \\
\hline Competitive Loan amounts on Purpose based Loans & 0.889 & 0.000 & 214 \\
\hline Permissible Amounts on Available security (Margin on security) & 0.805 & 0.000 & 214 \\
\hline Subsidies & $0.577^{* *}$ & 0.000 & 214 \\
\hline Chances of layoff of Interest or loan itself (more significant) & $0.901^{* * *}$ & 0.000 & 214 \\
\hline Security deposit Free loan & 0.842 & 0.000 & 214 \\
\hline Government promotional schemes & 0.621 & 0.000 & 214 \\
\hline Easy of getting loan & 0.655 & 0.000 & 214 \\
\hline
\end{tabular}

Source: Primary Data [*** highly significant (Strong Correlation) ** Least Significant

Table 4 depicts the Karl Pearson's coefficient of correlation of the opinion of the respondents on attributes of the bank they are associated with. Out of nine attributes included for the study four attributes are more significant, out of which the chances of layoff of interest or loan itself plays more significant with a correlation value of 0.901. the other important attributes with high significant values are competitive loan amounts on purpose based loans, security deposit free loan, permissible amounts on available security deposit with the correlation value of 0.889 , 0.842 and 0.805 respectively. Subsidies provide by the bank has a least correlation value and it is inferred from the table that is least significant.

Based on the above table and the correlation it is proved that the first hypothesis, that too alternative hypothesis is proved. So it can be reasonably stated that Chances of layoff of Interest or loan itself is a significant factor influencing for preferring cooperative banks over other peer group banks.

\section{Table 5: Descriptive Statistics}

\begin{tabular}{|l|l|l|l|}
\hline Factors & Mean & $\begin{array}{l}\text { Std. Devi } \\
\text { ation }\end{array}$ & N \\
\hline Subsidized Interest Loans & 4.62 & .714 & 214 \\
\hline Interest Rates & 2.70 & 1.445 & 214 \\
\hline Competitive Loan amounts on Purpose based Loans & 2.76 & .897 & 214 \\
\hline Permissible Amounts on Available security deposit (deviation is high) & 3.30 & 1.389 & 214 \\
\hline Subsidies & 4.52 & .948 & 214 \\
\hline Chances of layoff of Interest or loan itself & 4.32 & .946 & 214 \\
\hline Clean Loan: Security Free loan (deviation is high) & 3.29 & 1.387 & 214 \\
\hline Government promotional schemes & 4.72 & .578 & 214 \\
\hline Easy of getting loan (deviation is high) & 3.27 & 1.367 & 214 \\
\hline
\end{tabular}

Source: Primary Data 
Table 5 indicates mean and standard deviation values performed using the descriptive statistics. A set of nine factors were considered for the study, out of which four factors have high degree of deviation compared to other factors namely, interest rates, permissible amounts on available security deposit, security deposit free loan and easiness in getting loans with a standard deviation score of $1.445,1.389,1.387$ and 1.367 respectively. Government promotional scheme has a low degree of standard deviation with a score of 0.578 .

\section{Table 6: Nature of Association with Agriculture and Loan Sanctioning Effectives}

\begin{tabular}{|c|c|c|c|c|c|c|}
\hline \multirow[t]{2}{*}{ Dependent Variable } & Level & \multicolumn{5}{|c|}{ ANOVA } \\
\hline & Nature of Association with Agriculture & $\mathrm{N}$ & Mean & SD & $\mathrm{F}$ & Sig. \\
\hline \multirow[t]{3}{*}{$\begin{array}{l}\text { Credit Evaluation } \\
\text { Committee }\end{array}$} & $\begin{array}{l}\text { Agriculturist } \\
\text { (with no Income alternative) }\end{array}$ & 78 & 3.30 & 0.71 & \multirow[t]{3}{*}{4.53} & \multirow[t]{3}{*}{0.00} \\
\hline & Agriculturist(with Income alternative) & 136 & 3.10 & 0.68 & & \\
\hline & Total & 214 & 3.20 & 1.39 & & \\
\hline \multirow{3}{*}{$\begin{array}{l}\text { Collateral } \\
\text { Evaluation Powers } \\
\text { with Branch } \\
\text { Employees }\end{array}$} & $\begin{array}{l}\text { Agriculturist } \\
\text { (with no Income alternative) }\end{array}$ & 78 & 3.10 & 0.76 & \multirow[t]{3}{*}{5.78} & \multirow[t]{3}{*}{0.03} \\
\hline & Agriculturist(with Income alternative) & 136 & 2.90 & 0.89 & & \\
\hline & Total & 214 & 3.00 & 1.65 & & \\
\hline \multirow{3}{*}{$\begin{array}{l}\text { Clarity in Standard } \\
\text { Procedure for } \\
\text { Credit Evaluation }\end{array}$} & $\begin{array}{l}\text { Agriculturist } \\
\text { (with no Income alternative) }\end{array}$ & 78 & 3.30 & 0.711 & \multirow[t]{3}{*}{2.26} & \multirow[t]{3}{*}{0.00} \\
\hline & Agriculturist(with Income alternative) & 136 & 3.10 & 0.68 & & \\
\hline & Total & 214 & 3.01 & 1.39 & & \\
\hline \multirow{3}{*}{$\begin{array}{l}\text { Overall } \\
\text { effectiveness of } \\
\text { Credit Evaluation }\end{array}$} & $\begin{array}{l}\text { Agriculturist } \\
\text { (with no Income alternative) }\end{array}$ & 78 & 2.20 & 0.70 & \multirow[t]{3}{*}{4.69} & \multirow[t]{3}{*}{0.01} \\
\hline & Agriculturist(with Income alternative) & 136 & 2.80 & 0.64 & & \\
\hline & Total & 214 & 2.50 & 1.34 & & \\
\hline \multirow[t]{3}{*}{$\begin{array}{l}\text { Loan Sanctioning } \\
\text { Committee }\end{array}$} & $\begin{array}{l}\text { Agriculturist } \\
\text { (with no Income alternative) }\end{array}$ & 78 & 3.20 & 0.70 & \multirow[t]{3}{*}{4.90} & \multirow[t]{3}{*}{$0.09 * *$} \\
\hline & Agriculturist(with Income alternative) & 136 & 3.10 & 0.62 & & \\
\hline & Total & 214 & 3.15 & 1.32 & & \\
\hline \multirow[t]{3}{*}{$\begin{array}{l}\text { Sanctioning } \\
\text { Procedure }\end{array}$} & $\begin{array}{l}\text { Agriculturist } \\
\text { (with no Income alternative) }\end{array}$ & 78 & 2.90 & 0.69 & \multirow[t]{3}{*}{4.27} & \multirow[t]{3}{*}{$0.08 * *$} \\
\hline & Agriculturist(with Income alternative) & 136 & 3.12 & 0.67 & & \\
\hline & Total & 214 & 3.01 & 1.36 & & \\
\hline \multirow{3}{*}{$\begin{array}{l}\text { Consumer } \\
\text { Awareness On } \\
\text { Sanctioning } \\
\text { Procedure }\end{array}$} & $\begin{array}{l}\text { Agriculturist } \\
\text { (with no Income alternative) }\end{array}$ & 78 & 2.23 & 0.56 & \multirow[t]{3}{*}{5.27} & \multirow[t]{3}{*}{0.00} \\
\hline & Agriculturist(with Income alternative) & 136 & 3.14 & 0.68 & & \\
\hline & Total & 214 & 2.68 & 1.24 & & \\
\hline
\end{tabular}




\begin{tabular}{|c|c|c|c|c|c|c|}
\hline $\begin{array}{l}\text { Renewal } \\
\text { Procedure }\end{array}$ & \begin{tabular}{|l|}
$\begin{array}{l}\text { Agriculturist } \\
\text { (with no Income alternative) }\end{array}$ \\
Agriculturist(with Income alternative) \\
Total
\end{tabular} & \begin{tabular}{|l|}
136 \\
214
\end{tabular} & $\begin{array}{l}2.98 \\
2.70\end{array}$ & $\begin{array}{l}0.68 \\
137\end{array}$ & 4.32 & 0.00 \\
\hline $\begin{array}{l}\text { Political } \\
\text { Interference }\end{array}$ & \begin{tabular}{|l} 
Agriculturist \\
(with no Income alternative) \\
Agriculturist(with Income alternative) \\
Total
\end{tabular} & \begin{tabular}{|l|}
78 \\
136 \\
214
\end{tabular} & $\begin{array}{l}2.10 \\
2.29\end{array}$ & $\begin{array}{l}0.67 \\
0.68 \\
1.35\end{array}$ & 5.01 & 0.00 \\
\hline Corruption & \begin{tabular}{|l}
$\begin{array}{l}\text { Agriculturist } \\
\text { (with no Income alternative) }\end{array}$ \\
Agriculturist(with Income alternative) \\
Total
\end{tabular} & \begin{tabular}{|l|}
78 \\
136 \\
214
\end{tabular} & $\begin{array}{l}2.76 \\
2.98 \\
2.87\end{array}$ & $\begin{array}{l}0.75 \\
0.72 \\
1.47\end{array}$ & 4.11 & $0.09 * *$ \\
\hline Favoritism & \begin{tabular}{|l|l}
$\begin{array}{l}\text { Agriculturist } \\
\text { (with no Income alternative) }\end{array}$ \\
Agriculturist(with Income alternative) \\
Total
\end{tabular} & \begin{tabular}{|l|}
136 \\
214
\end{tabular} & $\begin{array}{l}2.11 \\
2.54\end{array}$ & $\begin{array}{l}0.62 \\
1.29\end{array}$ & 4.21 & 0.00 \\
\hline
\end{tabular}

Source: Primary Data

Table 6 indicates the nature of association with agriculture and loan sanctioning effectives using one way analysis of variance. Totally eleven factors were considered and included for the study and the results indicate that loan sanctioning committee, sanctioning procedure and corruption were not significant when compared to other factors. Other factors like credit evaluation committee, collateral evaluation powers with branch employees, clarity in standard procedure for credit evaluation, overall effectiveness of credit evaluation, consumer awareness on sanctioning procedure, renewal procedure, political Interference and favoritism were significant.

From the above table and interpretation it can be reasonably justified that, The Overall Credit
Evaluation Effectiveness of the DCCBs is significant from the perspective of respondents with different income pattern. Hence the alternative hypothesis HA2 of Overall Credit Evaluation Effectiveness of the DCCBs being significant from the perspective of respondents is proved.

\section{Presence of Credit Management Issue by Type of Loans in the Branch}

Mapping Tools was applied. "Multidimensional scaling usually plots the perceptions and preferences of individuals singly and as a group even when the information about the dimensions or bases of evaluations is minimal. Perceptual Mapping Analysis of Credit Management issue by type of loans in the branch has been shown below.

Figure 1: Perceptual Mapping Analysis of Credit Management issues in Purpose based loans offered

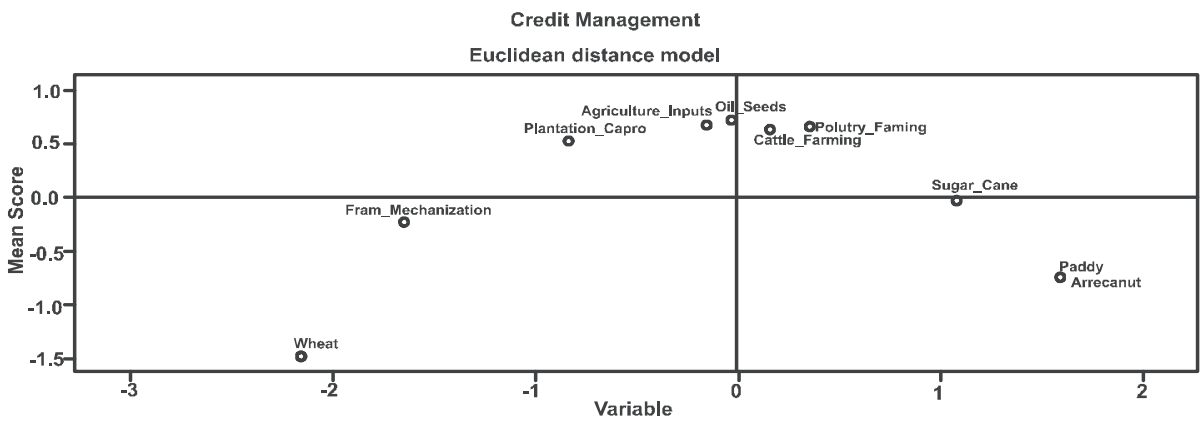


The above diagram depicts the perceptual mapping of the various types of loans facility offered by the bank to the customers. The perceptual map has four quadrants namely Lowlow, low high, high-low and high-high. The type of loan facilities fall under the high-high category which was most preferred by the customers are poultry farming, cattle farming and sugar cane. The bank can continue with the efforts they are offering to their customers for these types of loans. For the loans provided for farmmechanization and ware house loans has to take necessary action to improve on it because it was not preferred by the customers as they fall under the low-low quadrant.

From the above perceptual mapping, it can be reasonably stated that there are issues in Credit Management in Purpose based loans offered and the significance is proved. Hence the third alternative hypothesis is proved that is The DCCBs Credit Management issues in Purpose based loans offered are not significant.

\section{Conclusion}

On the basis of qualitative and quantitative analysis, and keeping in mind the aim and objectives of the Study, this research paper summarizes, broad Findings of the Study and the related Conclusions. The Conclusions of the Study pointed out a variety of issues and concerns, which need to be addressed for the evolution and effective implementation of proper credit management practices in the District Central Cooperative Banks in Shivmogga district. The credit management in banks has been the interest of the academician, researcher and the policy maker for a longer period of time. In addition to that the theme of credit management in DCCBs is socially highly relevant in today's business and economy. In this connection the present study captioned "Credit Management in co-operative Bank - an exploratory study of DCC Bank of Shivamogga District.

This study basically analyses the credit management policy and practices of DCCBs in Shivamogga District from both the perspectives of employees and the perspectives of the customers of the banks by conducting a survey. Finally for building co-operative institutions it need leadership with dedication and determination wedded to the ideology of cooperative. Unfortunately as the saying goes, "cooperation has failed for want of co-operative" naturally. Therefore co-operative can succeed with co-operation. If the mentioned suggestions are implemented in latter then spirit of cooperative credit system can serve as an effective instrument for the catalytic of agricultural and rural development.

\section{Reference}

Mayilsamy, R, "Loan Operations in District Central Co-operative Banks in India", Tamilnadu Journal of Cooperation, Vol.8, No.3, Jan, 2008, PP.6162.

Rais Ahmad and Nasrullah Bhat, "Recovery Performance of District Co-operative Banks in J \& K State", Monthly Public Opinion, Vol.XLIX, No.11, Aug, 2004, P.10.

Ramachandran, T, and Seilan,A, "Role of Kanyakumari District Central Co-operative Bank in Promoting Self-Help Groups", Indian Cooperative Review, Vol.44, No.1, July,2006,P.38.

Sarkale,R.N, Patil,H.K, Sananse,S.L, Patil,L.P and Nalawade,A.S, "Role of SDCC Bank in Agriculture \& Rural Development", Financing Agriculture, Vol.41, No.3, May-June, 2009, P.18.

Rais Ahmad and Nasurllah Bhat, Op.Cit, P.10.

Fulbag Singh and Balwinder Singh, "Funds Management in the Central Co-operative Banks of Punjab- An Analysis of Financial Margin", The ICFAI Journal of Bank Management, Vol.V, No.3, Aug, 2006, PP.75.

RBI College of Agricultural Banking, Op.Cit, PP.34.

Oliver Bright, A, "Role of Kanyakumari District Central Co-operative Bank (KDCCB) in Tsunami Credit", Kisan World, Vol.32, No.9, Sep, 2005, P.33. 
Fulbag Singh and Balwinder Singh, "Profitability Anonymous, 2004, Impressive performance of of the Central Co-operative Banks in Punjab - A NABARD during 2003-04. Nat.-Bank-NewsRev. Decomposition Analysis", Indian Co-operative Mumbai. 20 (1): 1-7.

Review, Vol.44, No.1, July, 2006, P.49. 